B.K., Santa Bahadur, T.B. Karki, J. Shrestha and P. Adhikari 2015. Productivity of maize genotypes under different planting dates. Our Nature. 13(1): 45-49. DOI: http://dx.doi.org/10.3126/ on.v13i1.14208

\title{
Productivity of Maize Genotypes under Different Planting Dates
}

\author{
Santa Bahadur B.K.", Tika Bahadur Karki, Jiban Shrestha and Parbati Adhikari \\ Nepal Agricultural Research Council \\ National Maize Research Program, Rampur, Chitwan, Nepal \\ *E-mail: shanta2015@live.com
}

Received: 2015.06.24, Accepted: 2015.08.19

\begin{abstract}
Genotypic yield potential of maize genotypes is greatly affected by planting dates. This study was conducted to determine optimum planting dates of maize genotypes in 2013/14 at Rampur, Chitwan, Nepal. Four genotypes namely RML-4/RML-17, RML-32/RML-17, ACROSS-9944/ACROSS-9942 and S99TLYQ-B were planted at every week from April to March. The experiments were laid out in randomized complete block design with four replications. The result of experiment showed that the highest production $(5565 \mathrm{~kg} / \mathrm{ha})$ was obtained in August followed by February (5266 kg/ha), June (4475 kg/ha) and July (4255 $\mathrm{kg} / \mathrm{ha})$ respectively. The lowest yield $(2572 \mathrm{~kg} / \mathrm{ha})$ was obtained in the month of November and December planting (3019 kg/ha). The highest grain yield was obtained in RML-4/RML17 (7392 kg/ha) and RML-32/RML17 (6606 kg/ha), ACROSS- 9944/ACROSS-9942 (5004 $\mathrm{kg} / \mathrm{ha}$ ) during August planting and higher yield of QPM variety S99TLYQ-B was obtained in the month February planting. Winter maize has higher production potential than the rainy season maize. Based on this experiment RML-4/RML-17, RML-32/RML17 and ACROSS9944/ACROSS-9942 should be planting in August (winter season) and S99TLYQ-B in February (spring season) for higher grain yield production.
\end{abstract}

Key words: Grain yield, planting dates and genotypes

\section{Introduction}

Maize is the second most important cereal crop in terms of both area and production and first staple food crop for the hills in Nepal. Its area, production and productivity is 8.49 million ha, 19.9 million $\mathrm{mt}$ and 2.3 $\mathrm{mt} / \mathrm{ha}$ (MoAD, 2013). It contributes about $25.02 \%$ in total cereal production, $6.54 \%$ in AGDP and 3.15\% in GDP (MoAD, 2013). The proportion of maize area consists of $70.23 \%$ in hills followed by $19.32 \%$ in Terai and $10.45 \%$ in mountain (MoAC, 2009/10). Almost all quantity of the maize produced in the mid (1.3 million $\mathrm{mt}$ ) and high hills (0.18 million $\mathrm{mt})$ directly utilizes in human consumption and a very little portion is fed to animals. However, more than $80 \%$ Tarai production $(0.38$ million $\mathrm{mt}$ ) is being utilized for poultry and animal feeds and remaining $20 \%$ is used as industrial $(10 \%)$ and human consumption (10\%) (NMRP, 2011).

It is grown in 875660 hectare of land with average yield of $2.119 \mathrm{t} / \mathrm{ha}$ (MoAC, $2009 / 10$ ) this yield is very low compared to that of neighboring countries. Either early planting or late planting can result in lower yield because the probability exists that unfavourable climatic conditions can occur 
after planting or during the growing season. Therefore, determination of sowing dates for maize genotypes is very crucial for better crop yield. In order for crop to best utilize moisture, nutrient and solar radiation, they must be grown from optimum sowing dates. Nepal is a small country with large environmental variation. Throughout the seasons of a year, weather conditions fluctuate a lot (Table 1). In this situation, the same genotypes may perform differently in different seasons. For maximization of benefit to farmers, they have to grow the best maize genotypes in the best season for location. It had been reported that maize grain yield was reduced when sowing was delayed to the end of October (McCormick, 1971). Maize planting date will effect on growing date, plant population, plant suitable growth, the time for developing reproductive organs, pollination and the time of harvest- so reaching the proper planting time for maize cultivation is particularly important in the success. Tanaka and Hara (1974) in India reported that variation in maize grain yield is due to the reduction in 1000 seed weight when sowing was delayed to the end of October. Very little work was done to determine optimum sowing dates of maize genotypes in Nepal. Therefore present study was carried out to determine optimum planting dates of maize genotypes for increased grain production in terai region of Nepal.

\section{Materials and methods}

The experiment was started at Rampur, Chitwan, Nepal during 2013/14. Maize was planted on sandy silt loam, strongly acidic soil $(\mathrm{pH}$ 5.0), medium in total nitrogen
$(0.130 \%)$, high in soil available phosphorous (279 $\mathrm{kg} / \mathrm{ha})$, high in soil available potassium $(215 \mathrm{~kg} / \mathrm{ha})$ and high in organic matter content $(2.70 \%)$ (NMRP, 2012). During this year, Four genotypes namely S99TLYQ-B RML4/RML17, RML32/RML17 and ACROSS9944/ACROSS-9942 were sown in every week from the second week of April 2013 to last week of March 2014. The design was randomized complete block design with four replications. In each month, the planting was replicated 4 times at seven days intervals. Spacing $75 \mathrm{~cm}$ row to row and $25 \mathrm{~cm}$ plant to plant spacing was maintained and two to three seeds are sown and after two weeks thinned one plants/hill. Plot size was 2 rows of 5 meter $(1.5 \mathrm{~m} \mathrm{x} 5$ $\mathrm{m})$ in which, whole plot was used to assess final harvest. Fertilizer @ FYM 10 t/ha and 120:60:40 kg NPK/ha was applied for each experiment. Half dose of nitrogen and full dose of phosphorous and potash was applied as basal dose at the time of final land preparation and remaining half of nitrogen was divided into two; one part applied at 20-24 days after sowing and second 40-45 days after sowing. Weeding and irrigation was done as per recommendations. Grain yield was calculated using ear weight at harvest assuming $80 \%$ shelling and adjusted to $15 \%$ moisture level. Analyses were performed using the MSTATC software. In addition the Fisher's least significant difference (LSD) was used to find significant differences among means.

\section{Results and discussion}

Determination of sowing dates for maize genotypes is very crucial for better crop 
Santa Bahadur B.K., Tika Bahadur Karki, Jiban Shrestha and Parbati Adhikari /Our Nature (2015), 13(1): 45-49.

Table 1. Meterological data at Rampur, Chitwan, Nepal during 2013-2014

\begin{tabular}{lccccc}
\hline \multirow{2}{*}{ Month } & \multicolumn{3}{c}{ Mean daily temperature $\left({ }^{0} \mathrm{C}\right)$} & Total Rainfall $(\mathrm{mm})$ & $\begin{array}{c}\text { Relative Humidity } \\
(\%)\end{array}$ \\
\cline { 2 - 4 } & Maximum & Minimum & Average & & 87.1 \\
April (2013) & 34.6 & 16.0 & 25.3 & 34.2 & 89.2 \\
May & 35.0 & 23.9 & 29.45 & 375.9 & 92.2 \\
June & 34.2 & 26.3 & 30.25 & 667.5 & 93.6 \\
July & 33.3 & 33.7 & 33.5 & 16.1 & 88.6 \\
August & 23.6 & 28.0 & 25.8 & 7.5 & 79.90 \\
September & 30.06 & 29.30 & 29.68 & 13.0 & 77.76 \\
October & 27.33 & 26.21 & 26.77 & 0.4 & 73.85 \\
November & 21.73 & 20.17 & 20.95 & 0.0 & 70.88 \\
December & 17.40 & 16.66 & 17.03 & 0.0 & 68.78 \\
January (2014) & 18.53 & 16.19 & 17.36 & 0.3 & 66.66 \\
February & 18.95 & 16.97 & 17.96 & 5.2 & \\
March & 21.93 & 20.91 & 21.42 & 3.4 & \\
\hline
\end{tabular}

(NMRP, 2014)

Table 2. Effect of different genotypes and date of planting on grain yield of maize ( $\mathrm{kg} / \mathrm{ha})$ at Rampur, Chitwan, during 2013/14

\begin{tabular}{|c|c|c|}
\hline SN Factor & Level & Grain yield (kg/ha) \\
\hline \multirow{4}{*}{1 variety } & 1. S99TLYQ-B & 2979 \\
\hline & 2. RML-4/RML17 & 4837 \\
\hline & 3. RML32/RML17 & 4846 \\
\hline & 4. ACROSS-9944/ ACROSS 9942 & 3029 \\
\hline F-test & ** & \\
\hline \multirow[t]{12}{*}{$2 \quad$ Date of planting } & 1. April (Baisakh) & 3913 \\
\hline & 2. May (Jesth) & 3370 \\
\hline & 3. June (Aasad) & 4475 \\
\hline & 4. July (Shrawan) & 4255 \\
\hline & 5. August (Bhadra) & 5565 \\
\hline & 6. September (Aaswin) & 3559 \\
\hline & 7. October (Kartik) & 3954 \\
\hline & 8. November (Mangsir) & 2572 \\
\hline & 9. December (Paush) & 3019 \\
\hline & 10. January (Magh) & 3238 \\
\hline & 11. February (Falgun) & 5266 \\
\hline & 12. March (Chaitra) & 3889 \\
\hline Grand mean & 3923 & \\
\hline F-test & $* *$ & \\
\hline$\frac{L^{2}}{\operatorname{LSD}_{0.05}}$ & 2234.1 & \\
\hline $\mathrm{CV} \%$ & 40.7 & \\
\hline
\end{tabular}

yield. Grain yield of maize influenced by genotypes and date of sowing is shown in the Table 2. Genotypes also showed highly significant effect on yield. The genotype promising hybrid RML-32/RML-17 produced the highest $4846 \mathrm{~kg} / \mathrm{ha}$ grain yield followed by RML-4/RML-17 (4837 kg/ha). S99TLYQ-B produced the lowest 2979 
Santa Bahadur B.K., Tika Bahadur Karki, Jiban Shrestha and Parbati Adhikari /Our Nature (2015), 13(1): 45-49.

Table 3. Interaction effect of different genotypes and date of planting (month) on grain yield $(\mathrm{kg} / \mathrm{ha})$ of maize at Rampur, Chitwan during 2013/14

\begin{tabular}{|c|c|c|c|c|}
\hline \multirow[b]{2}{*}{$\begin{array}{l}\text { Sowing } \\
\text { Month }\end{array}$} & \multicolumn{4}{|c|}{ Genotype } \\
\hline & S99TLYQ-B & RML-4/ RML-17 & RML32/RML17 & $\begin{array}{c}\text { ACROSS- 9944/ } \\
\text { ACROSS-9942 }\end{array}$ \\
\hline 1. April (Baisakh) & 3353 & 5225 & 4843 & 2624 \\
\hline 2. May (Jesth) & 3353 & 3897 & 4174 & 2057 \\
\hline 3. June (Aasad) & 2907 & 6894 & 5784 & 2314 \\
\hline 4. July (Shrawan) & 3169 & 5541 & 4934 & 3375 \\
\hline 5. August (Bhadra) & 3258 & 7392 & 6606 & 5004 \\
\hline 6. September (Aaswin) & 3741 & 3219 & 3483 & 3792 \\
\hline 7. October (Kartik) & 2388 & 3554 & 5690 & 4186 \\
\hline 8. November (Mangsir) & 2084 & 2775 & 3177 & 2252 \\
\hline 9. December (Paush) & 2305 & 3722 & 3653 & 2396 \\
\hline 10 . January (Magh) & 2584 & 4217 & 3897 & 2252 \\
\hline 11. February (Falgun) & 4198 & 6649 & 6520 & 3698 \\
\hline 12. March (Chaitra) & 2809 & 4963 & 5384 & 2400 \\
\hline Mean & 2979 & 4837 & 4846 & 3029 \\
\hline Grand mean & \multicolumn{4}{|c|}{3923} \\
\hline F-test & \multicolumn{4}{|c|}{$* *$} \\
\hline $\mathrm{LSD}_{0.05}$ & \multicolumn{4}{|c|}{2234.1} \\
\hline $\mathrm{CV}, \%$ & \multicolumn{4}{|c|}{40.7} \\
\hline
\end{tabular}

$\mathrm{kg} / \mathrm{ha}$. Effect of date of sowing was also highly significant in case of grain yield. The highest production was $5565 \mathrm{~kg} / \mathrm{ha}$ in August followed by February (5266 kg/ha), June $(4475 \mathrm{~kg} / \mathrm{ha})$ and July $(4255 \mathrm{~kg} / \mathrm{ha})$ respectively. The lowest yield was of month November $2572 \mathrm{~kg}$ and December planting (3019 kg/ha). Gurung et al. (2011) found that Rampur Composite and Arun-2 produced highest yield in August and lowest yield in May at Rampur Chitwan condition. Maize planted in August produced the highest yield (Lal, 1973; Saberi, 2014). Winter maize has higher production potential than the rainy season maize. Pests like insects, diseases, weeds are not problem during winter season but sometimes parrot is a problem during maturity period. Crop receives longer sunshine duration, higher rate of photosynthesis and assimilates utilization occurs during winter season. Fertilizer use efficiency is higher in winter season. These factors contribute higher production during winter season.

Interaction effect of date of planting and genotypes was found no significant (Table 3). RML-4/RML-17 and RML-32/RML17 produced the highest yields of $7392 \mathrm{~kg}$ and $6606 \mathrm{~kg} / \mathrm{ha}$ respectively followed by February planting) (6649 $\mathrm{kg}$ and 6520 $\mathrm{kg} / \mathrm{ha}$ ). Lowest yield was produced by the genotype S99TLYQ-B (2084 kg/ha) in November planting (Table 3).

\section{Conclusion}

The highest grain yield was obtained in RML-4/RML-17(7392 kg/ha) and RML32/RML17 (6606 kg/ha), ACROSS9944/ACROSS-9942 (5004 kg/ha) during August planting and higher yield of QPM variety S99TLYQ-B was obtained in the month February planting. Based on the result of single year experiment it can be concluded that the higher grain yield in 
Santa Bahadur B.K., Tika Bahadur Karki, Jiban Shrestha and Parbati Adhikari /Our Nature (2015), 13(1): 45-49.

Hybrid RML-4/RML-17, RML-32/RML17, and ACROSS-9944/ACROSS-9942 obtained by planting them in early winter season especially in September and S99TLYQ-B in spring season in February.

\section{References}

Gurung, D.B., B. Bhandari, J. Shrestha and M.P. Tripathi 2011. Effect of sowing dates and genotypes on productivity of maize in terai region of Nepal. International Research Journal of Applied and Basic Sciences 2(12): 446-451.

Lal, R. 1973. Effects of seed bed preparation and time of planting on Maize (Zea mays) in Western Nigeria. Experimental Agriculture 9: 303-313. http://dx.doi.org/10.1017/S0014479700010097

McCormick, S.J. 1971. The effect of sowing date on maize (Zea mays L.) development and yields of silage and grain. Proceedings of the Agronomy Society of New Zealand 1: 51-65.
MOAC 2009/10. Statistical Information on Nepalese Agriculture. Government of Nepal. Ministry of Agriculture and Cooperatives, Agri-Bussiness Promotion and Statistics Division, Singh Darbar, Kathmandu, Nepal.

MOAD 2013. Statistical information on Nepalese Agriculture 2012/2013. Agri-Business Promotion and Statistics Division. Ministry of Agriculture and Development. Singhadurbar, Kathmandu Nepal.

NMRP 2011. Annual Report 2010-11. National Maize Research Program, Rampur, Chitwan, Nepal.

NMRP 2012. Annual Report 2011-12. National Maize Research Program, Rampur, Chitwan, Nepal.

Saberi, A. 2014. The effects of sowing date on yield of silage corn hybrids. $J$. of Advanced Botany and Zoology1(3).1-4.

http://dx.doi.org/10.15297/JABZ.V1I3.03

Tanaka, A. and T. Hara 1974. Studies on the nutriophysiology of maize plant 10 . Grain yield as affected by sowing date. Fld. Crop Abstr. 27: 565. 